\title{
ORIGINAL ARTILCLE
}

\section{Thrombolysis in Acute ST Elevation Myocardial Infarction: Determination of Door to Needle Time in a Tertiary Medical Centre}

\author{
NIK AZLAN NM, MUHAMMAD YUSRI Y \\ Department of Emergency Medicine, Faculty of Medicine, Universiti Kebangsaan \\ Malaysia Medical Centre, Jalan Yaacob Latif, Bandar Tun Razak, 56000 Cheras, Kuala \\ Lumpur, Malaysia
}

\begin{abstract}
ABSTRAK
Waktu pintu kepada jarum untuk trombolisisis di Jabatan Kecemasan, Pusat Perubatan Universiti Kebangsaan Malaysia (ED, UKMMC) adalah penunjuk yang boleh mengurangkan kematian dan morbiditi pesakit infark miokardium beserta peningkatan ST (STEMI). Kajian ini dijalankan untuk mengenalpasti faktor-faktor yang mempengaruhi masa dari pintu ke jarum untuk STEMI dan adakah ia telah mencapai masa yang disyorkan iaitu 30 minit. Satu kajian keratan rentas dijalankan di kalangan pesakit yang telah dikenalpasti mengidap STEMI akut dan trombolisis dijalankan di ED, UKMMC dari Jun 2016 hingga ke Mac 2017. Borang pengumpulan data digunakan untuk mengumpul data demografik dan data klinikal pesakit termasuk waktu elektrokardiogram (ECG) pertama, masa penyediaan ubat trombolitik dan masa pembemberian ubat trombolitik kepada pesakit. Sejumlah 98 pesakit terlibat di dalam kajian ini. Majoriti pesakit (77.6\%) telah menerima ubat trombolitik dalam masa lebih daripada 30 minit selepas ketibaan di ED. Purata masa pintu ke jarum dalam ED UKMMC adalah 59.28 36.01 minit. Purata masa melakukan ECG ialah $7.19 \pm 8.08$ minit dan purata masa penyediaan ubat ialah $9.86 \pm 7.51$ minit. Daripada 76 (77.6\%) pesakit yang menjalani trombolisis selepas 30 minit ketibaan ED, 59.2\% (n=45) adalah disebabkan oleh rujukan pelbagai disiplin. Faktor lain ialah kelewatan dalam melaksanakan ECG pertama $19.8 \%$ ( $n$ = 15), interpretasi ECG pertama yang tidak tepat 9.2\% $(n=7)$ dan resusitasi pesakit sebelum trombolisis boleh dilakukan iaitu 9.2\% (n=7). Sebagai kesimpulan, kajian ini menunjukkan bahawa terdapat kelewatan trombolisis di hospital yang tidak boleh diterima dalam kes STEMI akut.
\end{abstract}

Kata kunci: peningkatan ST infark miokardium, elektrokardiogram, waktu pintu kepada jarum

Address for correspondence and reprint requests: Nik Azlan Nik Muhamad. Department of Emergency Medicine, Faculty of Medicine, Universiti Kebangsaan Malaysia Medical Centre, Jalan Yaacob Latif, Bandar Tun Razak, 56000 Cheras, Kuala Lumpur, Malaysia. Tel: +603-9145 5555 Email: nikazlanmuhamad@ hotmail.com 


\begin{abstract}
Door to needle (DTN) time for thrombolysis in the Emergency Department, Universiti Kebangsaan Malaysia Medical Centre (ED, UKMMC) is an indicator that can reduce mortality and morbidity of patients with ST Elevation Myocardial Infarction (STEMI). This study was conducted to determine factors that influence DTN time for acute ST Elevation Myocardial Infarction (STEMI) and whether it has achieved the recommended time of 30 minutes. A cross-sectional study was conducted among patients diagnosed with acute STEMI and thrombolysed in ED, UKMMC from June 2016 until March 2017. A data collection sheet was used to collect patient's demographic data and clinical data which included time of arrival to ED, time of initial electrocardiogram (ECG), time of drug preparation and time of thrombolytic delivery to the patient. A total of 98 patients were included in this study. Majority of patients (77.6\%) were thrombolysed more than 30 minutes following ED arrival. Mean DTN in ED, UKKMC was $59.28 \pm 36.01$ minutes. The mean door to ECG time was $7.19 \pm 8.08$ minutes and the mean drug preparation time was $9.86 \pm 7.51$ minutes. Out of $76(77.6 \%)$ patients that were thrombolysed after 30 minutes of ED arrival, 59.2\% $(n=45)$ were due to multiple disciplinary referral. Other factors were delay in performing initial ECG 19.8\% $(n=15)$, incorrect initial ECG interpretation 9.2\% $(n=7)$ and unavoidable need for prior resuscitation $9.2 \%(n=7)$. As a conclusion this study showed that there was an unacceptable delay in hospital thrombolysis for acute STEMI.
\end{abstract}

Keywords: electrocardiogram, door to needle time, ST elevation myocardial infarction

\section{INTRODUCTION}

Early reperfusion therapies such as thrombolysis and percutaneous coronary intervention $(\mathrm{PCl})$ can reduce mortality rates among patient with ST Elevation Myocardial Infarction (STEMI). In developing countries like Malaysia, thrombolytic therapy is a major treatment for patients who present with STEMI (Loch et al. 2013). Thrombolytic therapy has been estimated to save 65 lives per 1000 patient treated and maximum efficacy is achieved when treatment is initiated within one hour from the onset of symptoms (Yaylali et al. 2010). Door to needle time (DTN) is the interval between the patient's arrival at the emergency department and initiation of thrombolytic therapy (Jehangir et al. 2009). The Malaysian Clinical Practice Guideline on STEMI $2014(\mathrm{MOH}$ website) advised the implementation of a 30 minutes DTN (Azarisman et al. 2008). The Malaysian Ministry of Health National Patient Safety Indicator 2009 states that percentage of acute STEMI patient receiving thrombolytic therapy within 30 minutes of Emergency Department (ED) presentation should be more than $70 \%$. Early reperfusion 
is crucial as time lost is equivalent to myocardium lost (Kumolosasi et al. 2013).

There are three components which determine the time between the onset of myocardial infarction (MI) and administration of thrombolytic therapy. The three components are time in seeking medical attention, transport delay and door to needle time. Efforts to reduce these components will lead to improving survival of patients with acute Ml. The first two components are mostly dependent on patient awareness and efforts to seek medical attention. Data concerning DTN in a multidisciplinary teaching hospital such as Universiti Kebangsaan Malaysia Medical Centre (UKMMC) is lacking. This study was done to determine the average DTN time in a tertiary teaching Hospital. It also determines whether national target of DTN time in tertiary hospitals has been achieved and if not what are the factors leading to this delay

\section{MATERIALS AND METHODS}

The general objective of this study was to determine the mean DTN time for thrombolytic therapy in ED, UKMMC. Specific objectives were to determine door to ECG time, mean door to drug delivery time, mean time of drug preparation, percentage of achieved DTN time and factors causing delay on DTN time. Factors that were studied, included multiple referrals, incorrect ECG interpretation, delay drug preparation, need for resuscitation and unusual presentation.

This was a prospective cross- sectional study from May 2016 until May 2017 and conducted in UKMMC. This study included all patients who presented to ED, UKMMC and were diagnosed with acute STEMI and received fibrinolytic therapy in ED from May 2016 until May 2017. For each patient the demographic data and clinical data were recorded. The clinical data included the time onset of symptom, time arrival to ED UKMMC, time ECG done, and time drug preparation (Tenecteplase) and time thrombolysis start.

All patients diagnosed with Acute STEMI based on the current universal definition of AMI 2013 American College of Cardiology Foundation/ American Heart Association for the managementofSTelevation Myocardial Infarction and thrombolysed at ED, UKMMC from May 2015-May 2016 were included.

Diagnosis of STEMI was established based on the presence of any two of the following:

i. Ischemic symptoms :

Typical: Chest, upper extremity, jaw or epigastric discomfort with exertion or at rest. The discomfort associated with acute MI usually lasts at least 20 minutes. Often the discomfort is diffuse, not localized, not positional, not affected by movement of the region and it may be accompanied by diaphoresis, nausea or syncope.

Atypical: palpitations or cardiac arrest or even without symptoms especially in women, the elderly, diabetics, or post-operative and critically ill patients.

ii. Electrocardiogram:

Diagnostic ST elevation as defined by 
American Heart Association (AHA) for the Universal Definition of Myocardial Infarction as new ST elevation at the J point in at least 2 contiguous leads of $\geq 2$ $\mathrm{mm}(0.2 \mathrm{mV})$ in men or $\geq 1.5 \mathrm{~mm}(0.15$ $\mathrm{mV}$ ) in women in leads V2-V3 and/or of $\geq 1 \mathrm{~mm}(0.1 \mathrm{mV})$ in other contiguous chest leads or the limb leads. Presumed new left bundle brunch block on ECG was also included as a candidate for thrombolysis.

iii. Cardiac Biomarker:

Raised level of cardiac enzymes (Troponin T / CK MB)

Patient who received fibrinolytic therapy at others centers and patient who underwent primary $\mathrm{PCl}$ were excluded.

\section{DATA COLLECTION}

All patients with acute chest pain were triaged to critical or semi-critical area depending on the ACS diagnosis i.e. STEMI to critical area, NSTEMI (nonST elevation MI) to semi critical area. Patients were tagged and followed-up. Those who fulfilled inclusion criteria were approached for the study and informed consent was obtained from patient or patient's next of kin, once patient was stabilized or relatively stable. Consent included usage of patient's information and the results of blood investigation for the purpose of the study.

Data collection was conducted using a specifically designed data collection sheet (refer appendix.

\section{OPERATIONAL DEFINITION}

STEMI

: STEMI is a clinical syndrome defined by characteristic symptoms of myocardial ischemia in association with persistent electrocardiographic (ECG) ST elevation and subsequent release of biomarkers of myocardial necrosis.Diagnostic ST elevation as defined by AHA as new ST elevation at the J point in at least 2 contiguous leads of $\geq 2 \mathrm{~mm}(0.2 \mathrm{mV})$ in men or $\geq 1.5 \mathrm{~mm}(0.15 \mathrm{mV})$ in women in leads $\mathrm{V} 2-\mathrm{V} 3$ and/or of $\geq 1 \mathrm{~mm}(0.1 \mathrm{mV})$ in other contiguous chest leads or the limb leads.

\section{DTN}

: Time from hospital arrival until administration of the fibrinolytic therapy

Door to ECG

: Time from hospital arrival until ECG was performed

Order to drug delivery time (Tenecteplase preparation time)

: Time from decision for thrombolysis until delivery of drug.

Baseline Blood Pressure (BP)

: Blood Pressure before thrombolysis started

\section{SAMPLE SIZE}

Sample size was calculated using formula by Kish $\mathrm{L}$

$\mathrm{n}=\underline{\mathrm{z}} \times \mathbf{p}(1-\mathrm{p})$

$$
\Delta^{2}
$$

95\% confidence level

$\mathrm{z}=$ Degree of confidence level (1.96 
for $95 \%$ confidence level)

$$
=1.96
$$

$\Delta=$ Error of margin $0.05(5 \%)$

$\mathrm{p}=$ expected prevalence

Study by Loch et al. (2013) showed the prevalence of patient with DTN less than 30 minutes is $25 \%$. The confidence level was 95\%, therefore the sample size was

$$
\begin{aligned}
n & =\frac{1.96 \times 0.25(1-0.25)}{0.05^{2}} \\
& =147
\end{aligned}
$$

\section{STATISTICAL ANALYSIS}

Data was analyzed using SPSS
(Statistical Package for Social Science Version 19). Categorical data was presented in frequency and percentage. Continuous number was presented in mean \pm standard deviation.

\section{RESULTS}

During the one-year period of study, a total of 98 patients who presented with diagnosis of STEMI were thrombolysed and agreed to participate in the study. Among 98 patients, $88.8 \%(n=87)$ of the patients were males while $11.2 \%$ $(n=11)$ were females. The mean age was 56.3 years (SD, 13.8, range: 31116). Characteristic of patients were demonstrated in Table 1.

Table 1: Patient Characteristcs by Subgroups

\begin{tabular}{lcc}
\hline & $\mathbf{N}(\mathbf{n}=\mathbf{9 8})$ & $\%$ \\
\hline Age $($ mean \pm SD) & $56.3 \pm 13.8$ & \\
Age Ranges (years) & 8 & 8.2 \\
$31-40$ & 28 & 28.6 \\
$41-50$ & 30 & 30.6 \\
$51-60$ & 18 & 18.4 \\
$61-70$ & 10 & 10.2 \\
$71-80$ & 3 & 3.1 \\
$81-90$ & 1 & 1.0 \\
$111-120$ & & \\
Gender & 87 & 88.8 \\
Male & 11 & 11.2 \\
Female & & \\
Race & 48 & 49.0 \\
Malay & 24 & 24.4 \\
Chinese & 13 & 13.3 \\
Indian & 13 & 13.3 \\
Others & & \\
Comorbidity & 21 & 21.4 \\
Diabetes Mellitus & 28 & 28.6 \\
Hypertension & 19 & 19.4 \\
Ischaemic heart Disease & 18 & 18.4 \\
Smoker/Ex Smoker & 12 & 12.2 \\
Not known medical illness & & \\
\hline
\end{tabular}


Table 2: Door to Needle Times

\begin{tabular}{lcc}
\hline & $\mathbf{N}(\mathbf{n}=\mathbf{9 8})$ & $\%$ \\
\hline Mean & 59.28 & \\
Median & 54.00 & \\
30 minute & 22 & 22.4 \\
$>30$ minute & 76 & 77.6 \\
& & \\
\hline & $\mathbf{N}(\mathbf{n}=\mathbf{7 6})$ & $\%$ \\
\hline Door to Needle Time Ranges & & 38.8 \\
$31-55$ & 38 & 20.4 \\
$86-80$ & 20 & 5.1 \\
$106-130$ & 5 & 11.2 \\
$131-155$ & 11 & 1.0 \\
$206-230$ & 1 & 1.0 \\
\hline
\end{tabular}

The mean DTN time was $59.28 \pm$ 36.01 minutes with a median of 54.00 minutes. Among a total of 98 patients, only $22.4 \% \quad(n=22)$ of patients were thrombolysed within 30 minutes from the arrival to the hospital. The mean Door to Electrocardiogram (ECG) time were $7.19 \pm 8.08$ and the mean order to drug delivery time were $9.86 \pm 7.51$. The door to needle time was shown in the Table 2.

The study observed that a total of $76(77.6 \%)$ patients were thrombolysed beyond the 30 minutes target once arrived at hospital. Maximum delay of DTN time was 223 minutes.

Several factors were identified for causes of delay to deliver thrombolysis within 30 minutes of arrival to ED.
The commonest cause of delay was multiple referral, $59.2 \% \quad(n=45)$ of patients followed by delay to perform ECG within 10 minutes of arrival to hospital, $19.8 \%(n=15)$ of patients. Both, incorrect initial ECG interpretation and need for resuscitation before thrombolysis initiated contribute about $9.2 \%(n=7)$ each. The factors causing delay in thrombolysis were summarized in Table 3.

Among 98 patients who presented with acute STEMI, $39.8 \% \quad(n=39)$ of patients were diagnosed with anteroseptal STEMI whereby $22.4 \%$ $(n=22)$ of patients were diagnosed with Inferior STEMI. The less common area of infarct was Posterolateral STEMI $1.0 \%(n=1)$. Table 4 summarized the

Table 3: Factor-factor Causing Delay in Door to Needle Time

\begin{tabular}{lcc}
\hline & $\mathbf{N}(\mathbf{7 6})$ & $\%$ \\
\hline Multiple referral & 45 & 59.2 \\
Incorrect initial ECG & & \\
interpretation & 7 & 9.2 \\
Delay to perform ECG & 15 & 19.8 \\
Need to Resuscitation & 7 & 9.2 \\
Others & $\mathbf{2}$ & $\mathbf{2 . 6}$ \\
\hline
\end{tabular}


Table 4: Area of Myocardial Infarction.

\begin{tabular}{lcc}
\hline & $\mathbf{N}(\mathbf{n}=\mathbf{9 8})$ & \% \\
\hline Anterior & 3 & 3.1 \\
Anteroseptal & 39 & 39.8 \\
Inferior & 22 & 22.4 \\
Inferior with RV involvement & 13 & 13.2 \\
Inferior with RV and Posterior involvement & 9 & 9.2 \\
Inferoposterior & 6 & 6.1 \\
Extensive & 5 & 5.1 \\
Posterolateral & 1 & 1.1 \\
\hline
\end{tabular}

area in $\mathrm{Ml}$ involved during this study period.

\section{DISCUSSION}

The result from this study showed significant delay in administrating thrombolytic therapy for patient presented with acute STEMI. Although most of the guidelines recommend a DTN time of less than 30 minutes, our hospital failed to achieve this target in most of the patients. The mean $( \pm S D)$ DTN was $59.28 \pm 36.01$ with median $54.00 \pm 36.01$. Only $22.4 \% \quad(n=22)$ of patients presented to the ED were thrombolysed within 30 minutes of arrival to our ED. Compared to the local study done by Loch et al. in 2013, it showed only $24 \%$ of patients with acute STEMI received thrombolytic therapy within 30 minutes after presentation to the ED. The mean and median of DTN recorded by Loch et al. were 69 minutes and 50 minutes, respectively. Other study by Azarisman et al. (2008) showed that mean DTN at their Centre were 80.54 with only $20 \%$ of patient presented to their ED with acute STEMI thrombolysed within 30 minutes of presentation to their ED. The percentage was still low from our
National Patient Safety Indicator that suggested more than $70 \%$ of patient presented with acute STEMI receiving thrombolytic therapy within 30 minutes of presentation at the ED. If we compared the DTN with developed countries like United Kingdom, the mean DTN ranges from 20 minutes to 70 minutes. Whereby in USA, the median door to needle times is 70 min (Heath et al. 2003) with the faster DTN stated by Gonzalez et al. (1992) was 46 minutes. In Australia, Hourigan et al. (2000) stated the median DTN is 37 minutes after shifting to ED administration of thrombolytic therapy compared to median DTN 80 minutes before the intervention. Therefore, from this study, it can be stated that DTN in this ED was unacceptably delayed.

Our specific objective was to determine mean door to ECG time. It is because delay in obtaining the ECG is one of the modified factors that can contribute to delay DTN. The chest pain guideline (AHA) recommends that every patient with suspected Acute Coronary Syndrome (ACS) in ED should get an ECG immediately in the first 5-10 minutes after reaching the hospital. From this study, our 
mean $(+\mathrm{SD})$ Door to ECG time was $7.19 \pm 8.08$ which was less than 10 minutes as suggested by chest pain guideline. Unfortunately, 19.8\% $(n=15)$ patients in our study showed delay to perform ECG within 10 minutes upon arrival to our ED. The fastest ECG was done immediately after patient arrived to ED with the longest time to obtain the ECG was at 54 minutes from time of ED arrival. The study by Canadian, Vlahaki et al. 2008 stated that their median Door to ECG (DTE) time was 6 minutes. In India, the mean DTE was 6.98 minutes and study by Maharaj et al. (2012) showed their median DTE was 13 minutes.

Several factors were identified for causes of delay for thrombolysis within 30 minutes of hospital arrival. Multiple referral account for 59.2\% $\quad(n=45)$ patients, delay to perform ECG 19.8\% $(n=15)$ patients. Incorrect first ECG interpretation and need for resuscitation contribute to $9.2 \%(n=7)$ patients each. A study by Loch et al. (2013) stated that multiple referrals was the third causes of delay for early DTN in their Centre and showed multiple referral and hypertensive emergencies are the most causes of delay of DTN. Study in Cape Town also showed multiple referrals were the leading cause of delay in DTN (Maharaj et al. 2012). Whereby study by Jehangir et al. (2009) showed that incorrect initial ECG interpretation and need for resuscitation as the main cause of delay in DTN. It is assumed that once the patient is unstable such as hypotensive or underwent CPR, practitioners are reluctant to administer thrombolytic therapy. However, when contraindicated for thrombolytic therapy, i.e. acute ischemic stroke, pharmacological coronary reperfusion can be delayed for mechanical thrombectomy with better results. This would also avoid hemorrhagic complications from pharmacological thrombolysis (Hashim et al. 2018).

The anteroseptal STEMI 39.8\% $(n=39)$ was the most infarct area documented from our study. The second commonest infarct area was inferior wall, $22.4 \%(n=22)$ wall. This was followed by inferior with right ventricle (RV) 13.2\% ( $n=13)$, inferior with RV and posterior wall involvement $9.2 \% \quad(n=9)$, extensive $5.1 \% \quad(n=5)$, anterior $3.1 \%(n=3)$ and posterolateral infarct $1.1 \%(n=1)$. This area of infarct was not much different from other studies worldwide.

Some limitations of this study were identified. Comparing the sample size of the previous studies on the same subject, this study had a relatively small sample size. A larger prospective study may provide a better representation of our population.

\section{CONCLUSION}

The finding of this study showed unaccepted delay in thrombolysis of acute STEMI. Multiple referrals significantly delayed DTN time. This can be shortened with swift decision from an ED Medical Officer/Registrar or Specialist on call or on floor. Prehospital ECG can be implemented to shorten door to ECG time. Resuscitation or CPR of an unstable patient should not be a reason for delay in thrombolytic therapy. In the future, pre-hospital thrombolysis could 


\section{be implemented.}

\section{REFERENCES}

Azarisman, S.M., Ngow, H.A., Melor, P.A., Fauzi, M.A., Jamalludin, A.R., Sapari, S., Khairi, K., Noorfaizan, S., Oteh, M. 2008. Causes of inhospital delay for door-to-needle times in patients presenting with acute ST-elevation myocardial infarct in rural Malaysia. Ann Emerg Med 51(4): 530.

Gonzalez, E.R., Jones, L.A., Ornato, J.P., Bleecker, G.C., Strauss, M.J. 1992. Hospital delays and problems with thrombolytic administration in patients receiving thrombolytic therapy: a multicenter prospective assessment. Ann Emerg Med 21(10): 1215-21.

Hashim, E., Samshiyah, A.S., Nik Azuan, N.I. 2018. Mechanical thrombectomy as an alternative reperfusion therapy in acute ischaemic stroke associated with recent late presentation of st elevation myocardial infarction. Med \& Health 13(1): 215-9.

Heath, S.M., Bain, R.J.I., Andrews, A., Chida, S., Kitchen, S.I., Walters, M.I. 2003. Nurse initiated thrombolysis in the accident and emergency department: safe, accurate and faster than fast track. Emerg Med J 20(5): 418-20.

Hourigan, C., Mountain, D., Langton, P., Jacobs, I., Rogers, I., Jelinek, G., Thompson, P. 2000. Changing the site of delivery of thrombolytic treatment for ST elevation myocardial infarction from the coronary care unit to the Emergency Department greatly reduces door to needle time. Heart 84(2): 157-63.

Jehangir, W., Daood, M.S., Khan, M., Mallick, N.H., 2009. Evaluation of the door-to-needle time in patients undergoing fibrinolytic therapy after acute myocardial infarction. Pak J Physiol 5(2): 38-9.

Kumolosasi, E., Wei, W.S., Wee, C.E. 2013. The use of thrombolytic agents in acute myocardial infarction (AMI) patients. Int J Pharm Pharm Sci 5(2): 63-7.

Loch, L., Lwin, T., Mohd Zakaria, I., Zainal Abidin, I., Wan Ahmad, W.A., Hautmann, O. 2013. Failure to improve door to needle time by switching to emergency physician initiated thrombolysis for ST elevation Myocardial Infarction. Postgrad Med J 89(1052): 335-9.

Malaysian Clinical Practice Guidelines Management of Acute ST elevation Myocardial Infarction 2014 - $3^{\text {rd }}$ edition. http://www.moh.gov.my/ penerbitan/CPG/ 2017 [9 March 2018]

Maharaj, R.C., Geduld, H., Wallis, L.A. Door-toneedle time for administration of fibrinolytics in acute myocardial infarction in Cape Town. S Afr Med J 102(4): 241-4.
O'Gara, P.T., Kushner, F.G., Ascheim, D.D., Casey, D.E., Chung, M.K., de Lemos, J.A., Ettinger, S.M., Fang, J.C., Fesmire, F.M., Franklin, B.A., Granger, C.B., Krumholz, H.M., Linderbaum, J.A., Morrow, D.A., Newby, L.K., Ornato, J.P., Ou, N., Radford, M.J., Tamis-Holland, J.E., Tommaso, C.L., Tracy, C.M., Woo, Y.J., Zhao, D.X. 2013. 2013 ACCF/AHA guideline for the management of ST-elevation myocardial infarction: a report of the American College of Cardiology Foundation/American Heart Association Task Force on Practice Guidelines. J Am Coll Cardiol 61(4): e78-e140.

Vlahaki, D., Fiaani, M., Milne, W.K. 2008. A door-toneedle time of 30 minutes or less for myocardial infarction thrombolysis is possible in rural Emergency department. CJEM 10(5): 429-33.

Yaylali, Y.T. 2010. Door-to-needle times in acute myocardial infarction. Asian Cardiovasc Thorac Annals 18(2): 122-6.

Received: 16 April 2018

Accepted: 16 Jan 2019 